\title{
Structural Shockwaves: Consecutive Crises and Professional Mobility Among Judges and Prosecutors
}

Radu Andrei Pârvulescu

September 17, 2020*

\begin{abstract}
It is almost clichéd to speak of a Europe of crises, in which endless onslaughts (financial, migration, secession, plague) push the continent ever closer to collapse. But why should successive shocks be additive? Can the first shock dampen the second? By empirically investigating the professional mobility of judges and prosecutors in Romania over two consecutive crises - the 2017-2019 judicial reforms, and the 2020 COVID-19 pandemic - this article shows that a first shock can make a social structure more structurally robust to subsequent blows, while contextually amplifying the effects of secondary shocks. Methodologically, this article introduces the open-source Romanian Judicial Professions (1978-2020) database. Theoretically, it contributes to the study of consecutive crises by proposing a new concept, "structural shockwaves," and uncovering two emergent phenomena associated with sequential structural shockwaves - undertow and rip-currents.
\end{abstract}

keywords: COVID-19, judicial independence, mobility, professions, social theory, Romania

\section{(1) Introduction}

A trope of European social and political analysis, one strengthened by the COVID-19 pandemic, is "Europe in crisis," a generalisation of the older "fortress Europe"1 now under siege not merely by migrants but also by financial meltdown, secession, and most recently plague. The assumption, of course, is that crises are additive, with each one further weakening the outer walls. But is it really the case that every shock compounds the last one? Or is it more accurate to picture these events as waves hitting the shore, in which case retreating waves actually undercut the ones coming in?

These questions have wide scope, but they are particularly revelatory with regards to judicial politics, especially the fight over the professional power of judges and prosecutors. Attacks on the rule of law have featured prominently in media, policy, and academic discussions, as the politics of judicial weakening have manifested in EU countries that were supposed to have fully transitioned to WestEuropean judicial stability. Central to this debate has been the political engineering of professional crisis, often tied to purposive changes in the rates of recruitment, promotion, and retirement of judges and prosecutors (Kovács and Scheppele 2018). To the shrewd politician COVID-19 is one more usable crisis, so it behoves us to ask: has this pandemic exacerbated the politics of judicial staffing?

* Radu Andrei Pârvulescu is a doctoral candidate in the Department of Sociology at Cornell University, and a visiting scholar in the Department of Sociology, Anthropology, and Social Work at the University of Dayton. Address correspondence to Radu Andrei Pârvulescu, Department of Sociology, Uris Hall, 109 Tower Road, Ithaca, NY, 14850, USA; email: rap348@cornell.edu.

1 For the most recent review of the "fortress Europe” trope see the special edition of the European Journal of Cultural Studies, 2019(2):133-268. 
While this topic is especially relevant for countries experiencing acute struggle between magistrates and politicians, it is of wider interest. As politics around the world have become increasingly judicialised, with courts ruling on hot-button issues (e.g. climate change, human rights, corruption) formerly monopolised by governments and legislatures (Hirschl 2009), any sequence of events that threatens the career structure of state-based legal professions gains new salience. Studying a particular case of sequential shocks can uncover generic properties of consecutive crises. "Europe in crisis" does, after all, contain a grain of truth: since 2009 social and political shocks have come one after another. Investigating the emergent properties of sequential shocks can cultivate that grain to yield theoretical fruit.

This essay therefore tackles the issue of consecutive crises (including the COVID-19 crisis), with respect to state-based judicial professions: judges and prosecutors. It introduces and develops the concept of "structural shockwaves," deriving two phenomena emergent from the interaction of two or more shockwaves: undertow and rip-currents. It then employs these concepts to understand how political reform efforts and the COVID-19 pandemic have interacted in one civil-law system to generate outcomes that were not only unintended by the reformist politicians, but actually ran counter to their goals. The central, empirical research question is this: what are the effects of multiple, consecutive crises on the professional reproduction of state-based legal professions?

\section{(2) Structural Shockwaves and Judicial Professions}

\section{a. Shockwaves and Professional Structure}

Analysing consecutive crises requires sensibility to the order and timing of events. Social life has rhythm (Zerubavel 1981), and human actions are always both path dependent and contingent (Pierson 2000; White 1995). Sometimes, however, regular flows are jolted by crisis, which may have been brewing internally (e.g. Marxian overproduction) or come from afar (e.g. plague). Either way, crises are always mediated by the social structures in which people are imbricated, which explains why some can comfortably weather total war, while others are killed by job loss - frailty to change is variable.

Just as "normal" life has patterns, so too crises ebb and flow: indeed, some people and places are "prone” to crisis. Since "crisis" is a vague and loaded term, I introduce a more exact and transparent concept, "structural shockwave", defined as "a discrete event of sufficient magnitude to rapidly retard or enable the causal tendencies of a social structure."2 The particular social structures on which this essay focuses are judicial professions. I follow Abbott's "very loose definition that professions are exclusive occupational groups applying somewhat abstract knowledge to particular cases” (Abbott 1988:8). For our purposes, three constitutive elements of a profession stand out: its jurisdiction (i.e. the range of tasks that those professionals are preferentially entitled to accomplish [Abbott 1988:20]), its organisation (e.g. a bureaucratic hierarchy of judges versus a confederacy of lawyers in private practice; [Abbott 1988:79-85]), and its labour supply, that is, the total number of available professionals (Abbott 1988:129-34).

The interaction of these three elements of professional structure accounts for much observed variance in professional life. Notably, the size and quality of a profession's jurisdiction and the number of professionals are interdependent: if there are too many professionals and too few tasks then jurisdiction tends to grow, but if there is more jurisdiction than that profession can handle, then jurisdiction tends to shrink (Abbott 1988:249-50). Moreover, jurisdictional growth entails professional re-organisation as subfields are added, and conversely re-organisation affects professional size as old

2 The emphasis on causal tendencies, on retardants and catalysts, stems from Roy Bhaskar's (core) critical realism (Collier 1994:141-51) and Nancy Cartwright’s theory of Nomological Pluralism (Cartwright 1999). 
jobs are cut and new ones are opened; consequently, jurisdiction also changes (Abbott 1988:105-8). Abbott's theory further implies that if a profession is in equilibrium it will dynamically perpetuate its lucrative control of some task without bothering with expansion, contraction, attendant jurisdictional turf wars, or re-organisation.

Combining Abbott's theory of professions with the definition of structural shockwaves, we derive a methodological principle, namely that we can detect a shockwave hitting a stable profession because the wave will inhibit or magnify the profession's (causal) tendency towards mutually reinforcing stability in membership, jurisdiction, and organisation. Whether the effects of the wave will actually alter the profession structurally, changing its causal tendencies (and not simply mediating existing tendencies) is a medium-term question of at least five years. Short-term - less than five years - we can expect structural shockwaves to affect the manifestations of causes, and therefore the outcomes, but not the wellsprings of causation. ${ }^{3}$

\section{b. Consecutive Shockwaves: Undertow and Rip-currents}

What happens when one shockwave follows another in quick succession, i.e. within a five-year interval? The matter is more complex, because the effects of the second wave arise out of interaction with both the retreating first wave and the contextual changes wrought by that same first wave. This is not a question of either path dependence or contingency: with so much uncertainty, speaking of paths is presumptuous, while highlighting contingency is trite. We can, however, gain insight into the situation by theorising generic aspects of multi-wave interaction.

Pressing the nautical metaphor, we can discern an important phenomenon that arises beginning with two consecutive waves: undertow. All waves hitting the shore eventually recede into the ocean. Second waves typically break earlier, hitting the shore with less intensity, because they are undercut by the first wave in retreat. The larger the first wave, the stronger the contrasting force with which it hits the second. So a first, generic expectation about consecutive structural shockwaves is diminishing effect size of follow-up waves, since the undertow from the first wave dampens the force of the second - see Figure 1.

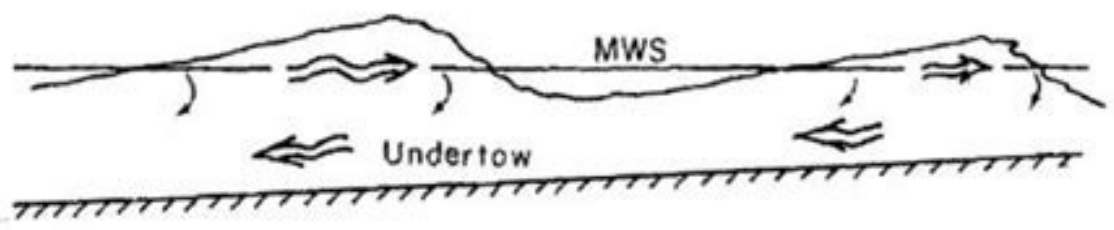

Figure 1: Diagram of Waves and Undertow (MWS = Mean Water Surface); photo courtesy of Wikipedia ${ }^{4}$

A second expectation is that two or more consecutive waves can generate unexpected rip-currents. As Figure 2 shows, a rip-current occurs when a retreating wave is channelled in a narrow gully on the sea floor. The funnel effect from the gully accelerates the current, while the underwater causality makes

3 Probably the quickest, whole-cloth transformation of modern legal professions on record was that occasioned by the post-war imposition of Stalinism. In Romania, where the pace of reform literally broke necks, this period lasted at least four years, and arguably twelve (Crăcană 2015:28-33).

4 Accessed on August 11, at https://en.wikipedia.org/wiki/Undertow (water waves)\#/media/File:Buhr Hansen and Svendsen ICCE 1984 Fig 1. png 
the current hard to detect, so swimmers are more likely to wander into a strong and invisible trap. Beachside rip-currents are usually known, and warning signs are placed in the affected area. But the ocean floor is ever changing, and particularly large waves can alter the underwater topography, creating the conditions for a new, unexpected rip current.

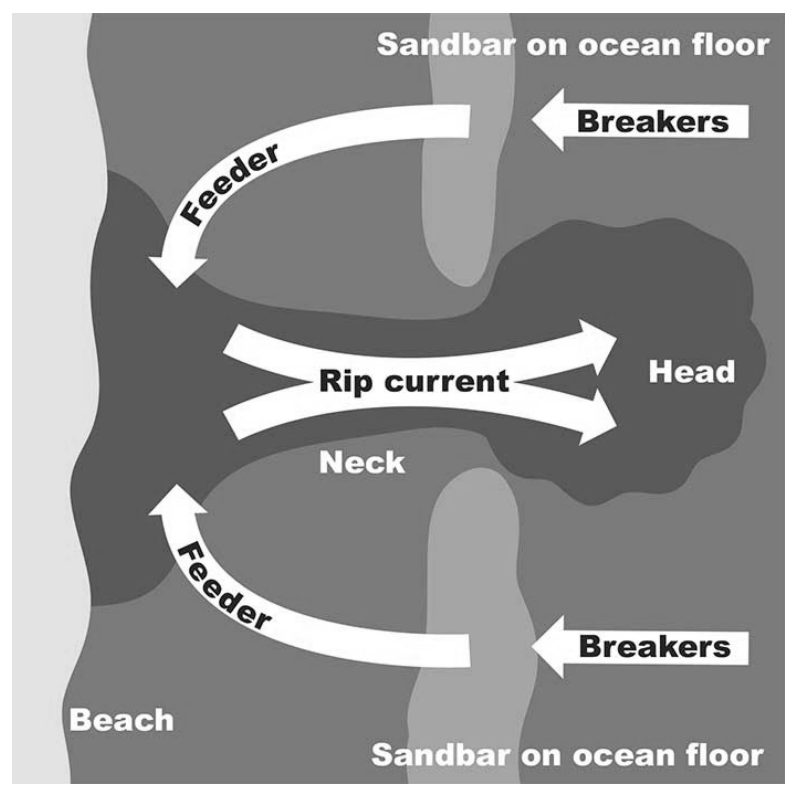

Figure 2: Diagram of Rip-current; photo copyright NOAA

So too with structural shockwaves. We can often predict the effects of a receding wave on the social structure: a sudden expansion in the number of professionals is often associated with smaller entry cohorts the following year. But what we cannot see until the second shockwave is whether the first wave alters the context of the profession enough so that the second wave behaves differently as it recedes. I stress, it is not a change in the professional structure that causes the emergence of new rip current (we assume that professional structure is robust in the short term), but rather a change in the profession's context, leading to a new manifestation of that profession's (unchanged) causal tendencies.

To summarise the theoretical section, I have introduced a new concept - the structural shockwave and have theorised two generic expectations about the interaction of multiple structural shockwaves:

a) two or more shockwaves create undertow, so the second wave will hit with less intensity than the first

b) a second (or third, fourth, etc.) shockwave can reveal new, unexpected rip-currents. which were not there before the first wave

Let us now see how these ideas can help us understand observed professional mobility.

\section{(3) Case Selection, Data, and Methods}

\section{a. The Case: Romanian Judges and Prosecutors, 2016-2020}

This article is dedicated to the state-based judicial professions, judges and prosecutors. There is significant cross-state variation in the extent to which prosecutors and judges can be considered

5 Accessed on August 11, 2020 at https://scijinks.gov/rip-currents/ 
professions, that is, exclusive occupational groups. ${ }^{6}$ US judges, for instance, are barely a profession: judges can be elected or appointed, usually in middle age after having spent their careers hitherto as lawyers or law professors. ${ }^{7}$ Compare this to the exclusivity of judges in most civil-law countries, where Immediately after law school (which is a bachelor degree, not a post-graduate specialisation) one competes for entry into judge school, whence begins a multi-decade career, with advancement resting on more exams. Much the same can be said for civil-law prosecutors. ${ }^{8}$

I therefore focus on judges and prosecutors in a civil law context, because here there is no doubt that these groups really are professions. The particular case that I analyse is Romania between 2016 and 2020, for two reasons. First, this country's judiciary is typical of civil law states, which comprise most of the world's legal systems - Appendix A briefly describes the Romanian judicial system. Second, despite their best efforts (and unlike their Hungarian and Polish counterparts) over the period of study Romanian political elites have proven unable to excise politics from the jurisdictions of judges and prosecutors.

Instead, 2017-2019 witnessed an inconclusive tug-of-war between the ruling coalition on the one hand, and magistrates and the opposition on the other: parliament tried to reform judicial procedure, key provisions were struck down by the Constitutional Court, the method for appointing head prosecutors was altered, the head of the ruling coalition was sent to jail, etc. Appendix B gives an overview of the legal-political drama. This inconclusive struggle did, however, create a rare situation in which the magisterial professions were both stable and prone to structural shockwaves, which lets us distinguish between the effects of subsequent shockwaves and the professional context, while keeping professional structure constant.

The population counts in Tables 1 and 2, which show minimal change in professional size, attest to one aspect of professional equilibrium between 2017-2019, despite constant attack. Regarding organisational jurisdictional stability, one must note that many reform laws were amended, prorogued (i.e. delayed) or struck down - further information in Appendix B. Furthermore, the laws that did pass, while politically ambitious, were structurally modest compared with the 2009-2012 overhaul of the civil and criminal codes, the organisational revolution of the 1990s, or the anti-independence judicial reforms in neighbouring Hungary (Kovács and Scheppele 2018:191-94). ${ }^{9}$

To conclude, the Romanian magisterial professions (judges and prosecutors) over 2016-2020 are well-suited to study the impact of consecutive crises, and of COVID-19 in particular, for two reasons. First, over this period the professional structure was stable but subject to shocks, hence one can analyse consecutive shocks while holding structure constant - Appendix C provides detailed justification for the periodisation. Second, we have excellent data on the judicial system, which lets us trace the effects of all shocks, including COVID-19, in great detail. Other systems have also been hit hard by this pandemic: education, business, and medicine come to mind. However, developments in these fields are harder to trace because we lack long-standing and constantly-updated information on the entire population of relevant professionals: I do not know of complete, publicly available, monthly-updated censuses of all schoolteachers, business owners, or medical professionals in any European country. Such information does exist, however, for Romanian judges and prosecutors.

$6 \quad$ I assume that the legal knowledge which judges and prosecutors apply is always abstract.

7 There is variance of course, among the states and between the local, state, and federal levels.

8 For comparative work on judges, see Bell(2006), Meador (1983), and Oliveira \& Garoupa (2011); for prosecutors, consult Gilliéron (2014).

9 One must distinguish the oft-debated transition from rule of law to rule by law (Tamanaha 2004:92-93) from the structural stability of a professional group. These phenomena are distinct, even though structural instability is often used by autocrats to lessen the rule of law. This paper primarily analyses the structural qualities of the professions. 


\section{b. Data and Methods: The Romanian Judicial Professions Database and Mobility Tables}

The data in this article are drawn from monthly, workplace-level employment rolls publicly released by the official, national, joint professional body of judges and prosecutors (together called "magistrates"), the Superior Council of the Magistracy (or CSM). For judges the workplace is the court, while for prosecutors it is the prosecutor's office, or "parquet".

This article's methodological contribution is to introduce not only a new, freely available database on Romanian judicial professions which stretches from 1988 to the present (and is constantly being updated) but also to release the open-source code that collects, cleans, and descriptively analyses the data. The challenge in compiling such a database is not actually getting the data ${ }^{10}$ but making it sensible. As is often the case with "big data" the big problem is identifying unique entities, in this case in order to trace the same professional across time, despite name changes, erroneous data-entry, missing observations, etc. This database stands or falls on the precision with which it assigns unique, person-level identifiers: both the code in Python ${ }^{11}$ and the data ${ }^{12}$ are open for inspection and replication.

The principal analytic tool used here is strictly descriptive, namely the intra-occupational mobility table: How many judges retired in year $\mathrm{X}$ versus year $\mathrm{Y}$ ? How many prosecutors climbed from low court parquets to tribunal parquets in year Z? I analyse five forms of mobility: entry/in (joining the profession), exit/out (retirement from the profession), mobility down (descending a judicial level, e.g. from Regional Court of Appeals to County Tribunal), mobility up (climbing the judicial hierarchy, e.g. from local Low Court to County Tribunal) and across/lateral mobility (changing workplaces in the same judicial level, e.g. from one County Tribunal to another).

I estimate yearly mobility by sampling one monthly employment roll per year, typically the month of July. ${ }^{13}$ I chose July because it is the most recent month for which employment rolls have been made available for all courts and parquets. ${ }^{14}$ Consequently, the total size of the profession (i.e. how many people were on the employment rolls for July of year X) refers strictly to the sampled month, e.g. July 2019. On the other hand, mobility metrics (entries, retirements, movements up, down, and across) should be interpreted as "changes occurring between July of year 1 and July of year 2," because we identify departure, promotion, etc. only by comparing a person’s positions in adjacent years.

For judges I sample all years between 2016 and 2020, inclusive. For prosecutors I omit the year 2018, and especially 2017-2018 mobility, because in 2018 the reporting format was overhauled, essentially changing how prosecutors' names were recorded. This introduces unacceptable levels of measurement error. Instead I report data for 2015-2016, a reasonable compromise as the prosecutors' measures for 2015-2016 are comparable to those from other years.

\section{(4) Findings}

Tables 1 and 2 show the size of each profession per year, as well as the inter-year occupational mobility for judges and prosecutors. Note that there are no metrics for "down" mobility from (municipal) low courts and parquets - there is nowhere to descend - just as there are no "up" or "across" figures for the

10 Though convincing court clerks to share employment rolls from the 1970s is not trivial.

11 Code available on GitHub at https://github.com/r-parvulescu/ro judicial professions; file “ecpr2020.py” contains exact code for this paper.

12 Full, post-2005 data up to July 2020 (which therefore covers the whole period studied in this article) is available at https://osf.io/gfjke/files/. As of this writing I only make the pre-2005 data available upon request, while I await legal advice regarding the data protections to which these archival materials may be subject.

13 For judges the following are sampled: July 2016, July 2017, July 2018, July 2019, July 2020. For prosecutors I sampled June 2015, June 2016, April 2017, July 2018, June 2019, and July 2020.

14 Data available online at www.csm1909.ro. 
High Court and associated parquet, as this is the singular peak. I present raw counts and not percentages because the size of each hierarchical level, and therefore of the profession(s) writ large, is highly stable across the periods under consideration. Since the theoretically meaningful baseline is equilibrium for both professions I highlight the few places in which we observe change across time. ${ }^{15}$

\begin{tabular}{|c|c|c|c|c|c|c|c|c|c|}
\hline \multicolumn{10}{|c|}{ Judges: Mobility Per Judicial Level } \\
\hline \multicolumn{5}{|c|}{ Size of Profession } & \multicolumn{5}{|c|}{ Count Entries } \\
\hline$\frac{\text { Year }}{\text { Judicial Level } \downarrow}$ & $\underline{2017}$ & $\underline{2018}$ & $\underline{2019}$ & $\underline{2020}$ & $\frac{\text { Year }}{\text { Judicial Level } \downarrow}$ & $\frac{2016-}{\underline{2017}}$ & $\frac{2017-}{\underline{2018}}$ & $\frac{2018-}{\underline{2019}}$ & $\frac{2019-}{\underline{2020}}$ \\
\hline Low Court & 2037 & 1988 & 2012 & 2148 & Low Court & 180 & 272 & 256 & 297 \\
\hline Tribunal & 1577 & 1640 & 1585 & 1549 & Tribunal & 17 & 19 & 21 & 10 \\
\hline Appellate & 894 & 974 & 935 & 915 & Appellate & 10 & 12 & 7 & 3 \\
\hline High Court & 122 & 119 & 114 & 114 & High Court & 0 & 1 & 1 & 0 \\
\hline Grand Total & $\underline{4630}$ & $\underline{4721}$ & $\underline{4646}$ & $\underline{4726}$ & & & & & \\
\hline \multicolumn{5}{|c|}{ Count Exits } & \multicolumn{5}{|c|}{ Count Down } \\
\hline $\begin{array}{l}\frac{\text { Year }}{\text { Judicial Level } \downarrow} \\
\downarrow\end{array}$ & $\frac{2016-}{\underline{2017}}$ & $\frac{2017-}{\underline{2018}}$ & $\underline{2018-}$ & $\frac{2019-}{\underline{2020}}$ & $\begin{array}{l}\text { Year } \rightarrow \\
\text { Judicial Level } \downarrow\end{array}$ & $\frac{2016-}{\underline{2017}}$ & $\underline{2017-}$ & $\underline{2018-}$ & $\frac{2019-}{\underline{2020}}$ \\
\hline Low Court & 111 & 112 & 123 & 89 & Tribunal & 9 & 14 & 6 & 4 \\
\hline Tribunal & 60 & 66 & 147 & 83 & Appellate & 6 & 6 & 8 & 5 \\
\hline Appellate & 40 & 36 & 84 & 63 & High Court & 0 & 1 & 0 & 0 \\
\hline High Court & 7 & 8 & 17 & 5 & & & & & \\
\hline \multicolumn{5}{|c|}{ Count Up } & \multicolumn{5}{|c|}{ Count Across } \\
\hline$\frac{\text { Year }}{\text { Judicial Level } \downarrow}$ & $\frac{2016-}{2017}$ & $\frac{2017-}{\underline{2018}}$ & $\frac{2018-}{\underline{2019}}$ & $\frac{2019-}{\underline{2020}}$ & $\begin{array}{l}\text { Year } \rightarrow \\
\text { Judicial Level } \downarrow\end{array}$ & $\frac{2016-}{\underline{2017}}$ & $\underline{2017-}$ & $\frac{2018-}{\underline{2019}}$ & $\frac{2019-}{\underline{2020}}$ \\
\hline Low Court & 119 & 230 & 124 & 83 & Low Court & 206 & 115 & 126 & 69 \\
\hline Tribunal & 63 & 92 & 45 & 42 & Tribunal & 31 & 9 & 20 & 25 \\
\hline Appellate & 12 & 5 & 11 & 5 & Appellate & 6 & 2 & 13 & 5 \\
\hline
\end{tabular}

Table 1: Size of the profession and mobility counts (entry, exit, down, up, across) for Romanian judges, 2016-2020

Starting with judges, 2018-2019 (July to July) witnessed unusually large numbers of retirements in all but the low courts. Judges can retire after 20-25 years on the job usually starting at 60 years of age, since law school counts towards this time. ${ }^{16}$ The rate of retirement for tribunal and court of appeals judges is lower in 2019-2020 than in the preceding period, though still high compared to earlier years.

15 I do not calculate contingency-table chi-squared metrics to test for the statistical significance of departures from the null (i.e. independence between year and count) because most cells in most tables contain insufficient observations. The only exception is the professional size tables, which fails to pass the test ( $\mathrm{p}=0.18$ for judges, $\mathrm{p}=0.44$ for prosecutors), which are entirely expected and uninformative results.

16 Over this period the age of retirement has been subject to heated debate but ultimately no change, the relevant articles being prorogued to January 1, 2020. See explanations for OUG 92/2018 and Law 239/2019 in Appendix B. 
Somewhat mechanically, 2019-2020 features more entries into the profession, ${ }^{17}$ as the CSM maintains size stability by opening/closing spots in judge school. ${ }^{18}$ The number of retirements ("up"), same-level transfers (“across"), and promotions ("up”) in low courts are unusually low in 2019-2020, which may be due to the difficulties of conducting career exams or relocating during quarantine. ${ }^{19}$

\begin{tabular}{|c|c|c|c|c|c|c|c|c|c|}
\hline \multicolumn{10}{|c|}{ Prosecutors: Mobility Per Judicial Level } \\
\hline \multicolumn{5}{|c|}{ Size of Profession } & \multicolumn{5}{|c|}{ Count Entries } \\
\hline $\begin{array}{l}\text { Year } \\
\text { Judicial Level } \downarrow\end{array}$ & $\underline{2016}$ & $\underline{2017}$ & $\underline{2019}$ & $\underline{2020}$ & $\frac{\text { Year } \rightarrow}{\text { Judicial Level } \downarrow}$ & $\underline{2015-}$ & $\underline{2016-}$ & $\underline{2018-}$ & $\underline{2019}-$ \\
\hline Low Court & 1155 & 1149 & 1121 & 1169 & Low Court & 131 & 108 & 98 & 151 \\
\hline Tribunal & 613 & 599 & 584 & 558 & Tribunal & 12 & 9 & 0 & 2 \\
\hline Appellate & 676 & 666 & 663 & 615 & Appellate & 4 & 4 & 2 & 0 \\
\hline High Court & 134 & 118 & 147 & 119 & High Court & 0 & 0 & 1 & 1 \\
\hline Grand Total & $\underline{\underline{2578}}$ & $\underline{\underline{2532}}$ & $\underline{\underline{2515}}$ & $\underline{\underline{2461}}$ & & & & & \\
\hline \multicolumn{5}{|c|}{ Count Exits } & \multicolumn{5}{|c|}{ Count Down } \\
\hline$\frac{\text { Year }}{\text { Judicial Level } \downarrow}$ & $\underline{\underline{2015-}}$ & 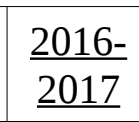 & $\begin{array}{l}\underline{2018-} \\
\underline{2019}\end{array}$ & $\underline{\underline{2019-}}$ & $\frac{\text { Year }}{\text { Judicial Level } \downarrow}$ & $\underline{2015-}$ & $\begin{array}{l}2016- \\
\underline{2017}\end{array}$ & $\underline{\underline{2018-}}$ & $\underline{2019}-$ \\
\hline Low Court & 59 & 87 & 60 & 64 & Tribunal & 17 & 20 & 12 & 4 \\
\hline Tribunal & 21 & 37 & 44 & 43 & Appellate & 18 & 23 & 22 & 11 \\
\hline Appellate & 20 & 33 & 29 & 64 & High Court & 2 & 3 & 3 & 2 \\
\hline High Court & 3 & 13 & 19 & 39 & & & & & \\
\hline \multicolumn{5}{|c|}{ Count Up } & \multicolumn{5}{|c|}{ Count Across } \\
\hline$\frac{\text { Year }}{\text { Judicial Level } \downarrow}$ & $\underline{2015-}$ & $\begin{array}{l}\underline{2016-} \\
\underline{2017} \\
\end{array}$ & $\underline{2018-}$ & $\underline{\underline{2019-}} \underline{\underline{2020}}$ & $\underset{\text { Year }}{\text { Judicial Level } \downarrow}$ & $\underline{2015-}$ & $\begin{array}{l}2016- \\
\underline{2017} \\
\end{array}$ & $\underline{2018-}$ & $\begin{array}{l}\underline{2019}- \\
\underline{2020} \\
\end{array}$ \\
\hline Low Court & 93 & 57 & 44 & 49 & Low Court & 92 & 83 & 72 & 21 \\
\hline Tribunal & 43 & 22 & 28 & 26 & Tribunal & 10 & 5 & 4 & 2 \\
\hline Appellate & 7 & 1 & 12 & 12 & Appellate & 18 & 5 & 10 & 9 \\
\hline
\end{tabular}

Table 2: Size of the profession and mobility counts (entry, exit, down, up, across) for Romanian prosecutors, 2015-2017, 2018-2020

17 By convention I count promotion from the departure state, so an up-movement in the low court cell indicates movement from low court to tribunal.

18 Nearly all entries are at low-court levels, i.e. almost all new recruits are taken from graduating cohorts of the National Institute of the Magistracy's (INM) two-year magistrate-training program. Direct entry to higher levels is possible for those with sufficient prior experience in a legal profession (e.g. a lawyer with ten years of experience), but this is rare, as can be seen by comparing the number of direct entries with the level of within-system promotions for any given year.

19 The careful reader may note that 2017-2018 featured unusually many promotions for tribunal and especially low court judges. I do not interpret these figures because in prior analyses, e.g. when sampling the month of April as opposed to July, there were no such outliers. I therefore suspect the high figures in the current version to be artefactual. For the next iteration of this paper I plan to calculate all metrics four times, once for one month from each season (e.g. January, April, July, October) and report their average and standard deviation, which should wash out artefactual outliers. 
Turning to the prosecutors, most noteworthy is the high number of departures at the Court of Appeals and High Court parquets, with little change at the lower levels. ${ }^{20}$ There is again a predictable correlation between increased exits and entries in 2019-2020. Up-movements are consistent across years. Part of the reason may be that cross-level movements to the specialised agencies (DNA and DIICOT, specialised prosecutor agencies; cf. Appendix A) occur via ad hoc, individual applications and interviews, not scheduled, collective entrance exams. Finally, we note that "down" and "across" movements are low for all prosecutors in 2019-2020.

\begin{tabular}{|c|c|c|c|c|c|c|c|c|}
\hline \multicolumn{9}{|c|}{ Prosecutors - Retirements per Court of Appeals Region / Agency } \\
\hline$\underline{\text { Year } \rightarrow}$ & \multicolumn{2}{|c|}{$\underline{2015-2016}$} & \multicolumn{2}{|c|}{$\underline{2016-2017}$} & \multicolumn{2}{|c|}{$\underline{2018-2019}$} & \multicolumn{2}{|c|}{$\underline{2019-2020}$} \\
\hline $\begin{array}{l}\text { Metric } \rightarrow \\
\text { Unit } \downarrow\end{array}$ & Count & $\begin{array}{l}\text { Percent } \\
\text { of Pop. }\end{array}$ & Count & $\begin{array}{l}\text { Percent } \\
\text { of Pop. }\end{array}$ & Count & $\begin{array}{l}\text { Percent } \\
\text { of Pop. }\end{array}$ & Count & $\begin{array}{l}\text { Percent } \\
\text { of Pop. }\end{array}$ \\
\hline $\begin{array}{l}\text { High Court } \\
\text { Parquet }\end{array}$ & 3 & $2 \%$ & 13 & $10 \%$ & 19 & $13 \%$ & 39 & $27 \%$ \\
\hline DIICOT & 7 & $3 \%$ & 12 & $7 \%$ & 9 & $3 \%$ & 22 & $8 \%$ \\
\hline DNA & 2 & $2 \%$ & 2 & $1 \%$ & 2 & $1 \%$ & 13 & $9 \%$ \\
\hline Alba Iulia & 8 & $7 \%$ & 7 & $5 \%$ & 6 & $5 \%$ & 12 & $10 \%$ \\
\hline Bacău & 9 & $9 \%$ & 5 & $5 \%$ & 6 & $6 \%$ & 6 & $6 \%$ \\
\hline Brașov & 7 & $8 \%$ & 4 & $5 \%$ & 3 & $3 \%$ & 7 & $7 \%$ \\
\hline București & 15 & $3 \%$ & 24 & $5 \%$ & 25 & $5 \%$ & 25 & $5 \%$ \\
\hline Cluj & 6 & $4 \%$ & 10 & $7 \%$ & 7 & $5 \%$ & 9 & $6 \%$ \\
\hline Constanța & 1 & $1 \%$ & 4 & $5 \%$ & 8 & $9 \%$ & 14 & $15 \%$ \\
\hline Craiova & 8 & $5 \%$ & 17 & $9 \%$ & 7 & $4 \%$ & 15 & $9 \%$ \\
\hline Galați & 1 & $9 \%$ & 5 & $5 \%$ & 15 & $15 \%$ & 6 & $7 \%$ \\
\hline Iași & 0 & $0 \%$ & 8 & $7 \%$ & 7 & $6 \%$ & 3 & $3 \%$ \\
\hline Oradea & 4 & $5 \%$ & 10 & $13 \%$ & 4 & $5 \%$ & 4 & $5 \%$ \\
\hline Pitești & 5 & $5 \%$ & 9 & $9 \%$ & 4 & $4 \%$ & 7 & $7 \%$ \\
\hline Ploiești & 4 & $3 \%$ & 16 & $11 \%$ & 14 & $11 \%$ & 15 & $12 \%$ \\
\hline Suceava & 5 & $6 \%$ & 6 & $7 \%$ & 1 & $1 \%$ & 2 & $3 \%$ \\
\hline Timișoara & 8 & $6 \%$ & 11 & $8 \%$ & 7 & $5 \%$ & 9 & $7 \%$ \\
\hline Târgu Mureș & 1 & $1 \%$ & 2 & $3 \%$ & 8 & $11 \%$ & 2 & $3 \%$ \\
\hline
\end{tabular}

Table 3: departure counts and percent departures (relative to yearly population), per appellate area or agency, for prosecutors 2015-2016, 2018-2020; rows pertaining to elite prosecutor units are highlighted

20 I have categorised the DNA and DIICOT at the court of appeals level as opposed to the tribunal level, a somewhat arbitrary choice and one that I do not think is consequential for this analysis. 
Given the high rate of departures of prosecutors at the higher levels it is worth breaking down departure rates by court of appeals area and/or agency - see Table 3. By “court of appeals area” I mean all courts of whichever level within a certain geographic region under he jurisdiction of a court of appeals. The two specialised agencies, the DNA and DIICOT, only accept prosecutors with a minimum six to ten years of experience, ${ }^{21}$ have their own internal territorial divisions, and employ as many prosecutors as an appeals area. Further details on the judicial system can be found in Appendix A.

The take-away from Table 3 is that most of the Court of Appeals parquet departures in 2019-2020 are due to retirements from the DNA, DIICOT, and especially the PICCJ (the parquet corresponding to the High Court). One can therefore say that 2019-2020 (at least until July) has featured a minor exodus from the higher reaches of the prosecutors, including a third of High Court prosecutors. Judges feature no such clustering of retirements, and also have no special agencies.

One should also ask how much year-level mobility fluctuates by season, especially with regards to 2019-2020, since Romania declared a state of emergency in March 2020. If spring-summer 2020 features more departures than usual, while retirements in fall-winter 2019 follow precedent, we may conjecture that change was largely due to COVID, which hit Romania in early spring 2020. Withinyear variance is not perfect evidence because of multi-month bureaucratic delays between submitting a retirement request and having one's name struck off of the employment rolls. Still, such variance can be telling.

\begin{tabular}{|c|c|c|c|c|c|c|}
\hline \multicolumn{7}{|c|}{ Judges: Within-Year Retirement Counts } \\
\hline \multirow[b]{2}{*}{ Month Span $\downarrow$} & \multirow[b]{2}{*}{ Judicial Level $\downarrow$} & \multicolumn{5}{|c|}{$\underline{\text { Year } \downarrow}$} \\
\hline & & $\underline{2015}$ & $\underline{2016}$ & $\underline{2017}$ & $\underline{2019}$ & $\underline{2020}$ \\
\hline \multirow{4}{*}{$\begin{array}{l}\text { September- } \\
\text { December }\end{array}$} & Low Court & 20 & 44 & 35 & 15 & \multirow{4}{*}{ NA } \\
\hline & Tribunal & 13 & 17 & 14 & 25 & \\
\hline & Appellate & 12 & 14 & 11 & 15 & \\
\hline & High Court & 2 & 1 & 2 & 2 & \\
\hline \multirow{4}{*}{ April-June } & Low Court & \multirow{4}{*}{ NA } & 21 & 23 & 24 & 12 \\
\hline & Tribunal & & 13 & 22 & 8 & 7 \\
\hline & Appellate & & 6 & 9 & 8 & 3 \\
\hline & High Court & & 0 & 2 & 2 & 0 \\
\hline
\end{tabular}

Table 4: Within-Year Retirement/Out Mobility for Judges, 2015/2016-2017, 2019-2020

Table 4 shows April-July out/retirement counts ${ }^{22}$ for every year between 2017-2020 (inclusive), and September-December counts for 2015, 2016, 2017, and 2019, for judges. Unfortunately, we do not have fall-winter data for 2018, as employment rolls for September/December 2018 have never been released. The signal is weak, indicating that fall-winter 2019 features more Tribunal-level departures

21 The minimum age of entry into the specialised agencies rose from six, to eight years (in July 2018) and then to ten years (in February 2019). For a log of the legislative changes, see Law 2017/2018 of 20 July 2018 and OUG 92/2018 of 16 October 2018 in Appendix B.

22 That is, the number of judges retiring between April and July of any given year, e.g. 2018. 
than previous years, while the departure rate for spring-summer 2020 does not deviate from precedent. In other words, the wave of 2019-2020 departures is not associated with increased departures during the COVID-19 state of emergency period. Again, these comparisons are indicative at best: the bulk of retirements might well have occurred from January to March. ${ }^{23}$

Regrettably, I cannot run a similar test for the prosecutors, because data on their month-level employment are much less consistent. To legitimately compare within-year mobility across years we must always use the same month gap, for instance April-June. Unfortunately, no two years from 2015 to 2020 contain data on exactly the same months. Moreover, sometimes only a fraction of the prosecutors are reported for month $\mathrm{X}$, but all reported for the next month: such is the case for June and July $2020 .^{24}$

In conclusion, investigation of prosecutors' and judges’ professional mobility between 2015/2016 and 2020 reveals the following:

- For both judges and prosecutors, 2019-2020 featured more entries than previous years

- Judges were especially likely to retire from 2018 to 2019, and somewhat less likely to do so in 2019-2020 (though still more than in 2016-2018);

- Month-level data weakly shows that the 2019-2020 retirement rate was not unusually affected by developments in spring-summer 2020, the period including the COVID lock-down

- Low-court judges experienced less “out”, “up” and “across” mobility in 2019-2020 than in preceding years.

- $\quad$ Mid to high-level prosecutors retired more in 2019-2020 than in the three preceding years - These departures came predominantly from the elite prosecutor agencies

- All levels of prosecutors experienced less “down” and “across” mobility in 2019-2020.

\section{(5) Substantive and Theoretical Implications}

\section{a. Substantive Implication 1: the Irony of Political Interference}

What are we to make of the findings summarised above? With regards to the politics of judicial appointments, that is, the manipulation of state-based judicial professions (i.e. judges and prosecutors) by elected officials, I dare say that political elites do not require exogenous structural shockwaves to push their agenda: they can easily engineer their own. As the legislative saga in Appendix B shows, the magistrates' professional equilibrium between jurisdiction, organisation, and professional size was under attack well before COVID-19, with the consequence that judges' retirement rate peaked in 20182019, and actually decreased during the COVID shock. I suspect that a similar, though less intense, dynamic also occurred with the prosecutors, if only because most of the attempted legal reforms have targeted "magistrates", the common legal category of both judges and prosecutors. ${ }^{25}$ In the absence of

23 Another possible confound with the spring-summer COVID hypothesis is that a bill featuring major pension reductions for magistrates (Bill 362/2019) passed through parliament on 16 June 2020, well into the COVID-19 lock-down. Consequently, magistrates might have preferentially retired in spring-summer 2020 not because of COVID-19 but in anticipation of the bill reducing their pensions. This interpretation is not supported by the data (which shows no unusual increase in spring-summer 2020), and would have been improbable in any case, because a) pensions are reduced regardless of when one retires, b) the bill has not yet become law (as of August 8, 2020), being under review by the constitutional court, and c) the bill had been initiated in October 2019, giving magistrates ample time to react before spring-summer 2020; see Appendix B for further details.

24 Results available upon request.

25 Attacks on that commonality (e.g. Law 242/2018; see Appendix A ) did not go so far as to abolish it. 
more consistent month-level data, however, it is impossible to verify claims regarding prosecutors. ${ }^{26}$ Overall, however, I conclude that political elites have not (thus far, at least) used the COVID-19 shock to opportunistically alter the magistracy, partly because of government turnover and more pressing public-health priorities, but also because politicians were already sowing and harvesting shocks of equal or greater intensity, as the 2017-2019 reforms demonstrate. The marginal, political utility of the COVID-19 shockwave seems to be lower because it joined an already crowded field.

In fact, and in a highly ironic twist of fate, these endogenous structural shocks may actually have made the judicial professions more robust to the effects of COVID-19. The destabilising professional reforms caused a wave of retirements before COVID-19, probably among those more likely to leave anyway, such as senior judges and prosecutors around retirement age. This gave the professional bodies time to react and open more spots in magistrate school, thereby growing entry cohorts. Larger entry cohorts then synchronised, unintentionally, with a reduced departure rate at precisely the entry level which probably was caused by COVID. Consequently, there has been a slight increase in the net numbers of both judges and professionals.

Of course, the reforms aimed to remove senior magistrates, and met with some success. But if the hope was to make these professions generally more vulnerable to shockwaves ${ }^{27}$ the results are mixed: fewer judges retired in 2019-2020 than in the preceding year, while the opposite is true for prosecutors. Moreover, limiting the flow of new magistrates was also a goal of the original reformers, to be achieved by extending mandatory magistrate school from two years to four. ${ }^{28}$ This would have starved the magistracy of two whole entry cohorts, leading to a roughly $20 \%$ reduction in the number of both judges and prosecutors, which, compounded with the increased retirement, would really have been a crisis. $^{29}$ As it turns out, the opposite has occurred. COVID has not, so far, weakened these professions.

\section{b. Substantive Implication 2: The Swelling Tide of Entrants}

A second substantive implication is that the hullabaloo around judicial professions has impacted the professions' larger political context. My first claim is that the fight over the length of mandatory, postgraduate, magistrate-school (two years versus four) has generated consensus among political elites on the need for smooth recruitment into the magistracy. ${ }^{30}$ At the same time, the endless debates on the

26 Another possibility is that the high number of senior prosecutors retirements in 2019-2020 is due to all three of the elite agency heads being replaced in February 2020. It is unclear why this would cause an exodus, because the preceding period, in which these agencies were steered by seconds-in-command on interim mandates, was clearly less stable, but perhaps sufficient prosecutors were displeased with the appointments, which are political. This is a hypothesis we can only test with data for spring-summer 2021, and even then it will be difficult to tease out the appointment vs COVID effects, since the state of emergency began in March 2020, only one month after the new appointments.

https://www.rri.ro/en gb/numiri controversate la sefia parchetelor-2612341

27 It is reasonable to conclude that the Romanian 2017-2019 reforms were meant to make the magisterial professions more vulnerable to structural shockwaves. Engineering such vulnerability was the thrust of similar reform efforts in nearby countries (cf. Kovács and Scheppele [2018]). In Romania the purpose was to make such professions more susceptible to politically-induced shockwaves (i.e. political manipulation), but the result would have made the professions weaker to economic or plague shocks as well, because all such shockwaves affect the same thing: the propensity of people to enter or leave the magistracy, hence the number of magistrates available, hence judicial efficacy.

28 Using law 242/2018, which was subsequent amended and unfavourably ruled on by the Constitutional Court; see Appendix A.

29 Of course those numbers would have bounced back in about five years, if past trends would have held. But by that point enough professional instability would have been generated to achieve the short-term goals of the ruling coalition, namely to reduce the ability of magistrates to jail leading politicians (including the head of said ruling coalition), to facilitate pushing through further judicial reforms, and to make it into the next electoral cycle with a win under their belt. 
national justice system have publicised an older shortcoming, namely the high ratio of cases to judges/prosecutors. ${ }^{31}$

Now consider the combination of atypically small, COVID-induced rates of promotion and transfer for those in the lower reaches of the judicial hierarchy, with the increased rate of retirement for the upper levels. These are surface-level changes wrought by structural shockwaves mediating existing structures, and not by constitutive changes in the relationships between jurisdiction, organisation, and professional size, so there is no reason to think that this new hierarchical distribution is a new equilibrium. Consequently, in the near future we are likely to witness a typical organisational scene: pent-up ambition in the lower ranks will meet a surfeit of open positions higher up, causing a rash of departures from the entry levels, which will occasion more recruitment from law schools. ${ }^{32,33}$ Combined with newfound political and public openness to a bigger and better magistracy, such heightened professional mobility will generate at least one more year, maybe several, of unusually large entry cohorts. We are, in other words, on the cusp of a minor expansion of the magistracy. ${ }^{34}$

\section{c. Theoretical Lessons: The Power of Undertows and Rip-currents}

The theoretical ambition of this paper has been to highlight how sequential crises, conceptualised as consecutive structural shockwaves, have dynamics of their own, which predictably influence causal patterns in unstable situations that are otherwise resistant to diachronic analysis based on path dependence and/or contingency. In particular, I have claimed that two phenomena emergent from multi-wave interaction, undertow and rip-currents, can help account for both enabling and retarding causal factors. ${ }^{35}$

To make these theoretical points clearer, I will restate the "substantive" findings in more abstract terms. Generally, a sequence of two waves, one endogenous (the reform attempts) the other exogenous (COVID-19), interact to generate causal dynamics that would otherwise not have occurred. One emergent dynamic is undertow, when a retreating first wave clashes with an advancing second wave, thereby dampening and altering that second wave's effects. In our case, the interaction of the reformand COVID-induced structural shockwaves led to slight net growth of judicial profession and a reduction of judges' retirement rate, as opposed to decreased professional size and increased

30 I back this claim by referencing official statements, each from a different political source often at loggerheads with the other two: statements on OUG 7/2019 (which reverted from 4-year back to 2-year magistrate school), and Constitutional Court Decision 221/2020 (which nullified whole cloth the article proposing 4-year education) (for these two, see Appendix A), as well as by a new bill presented for public consultation by the Ministry of Justice on 22 June, 2020 (available at http://www.just.ro/proiectul-de-lege-privind-unele-masuri-temporare-referitoare-la-concursul-deadmitere-la-institutul-national-al-magistraturii-formarea-profesionala-initiala-a-judecatorilor-si-procurorilorexamenul/).

31 Compared to other EU countries, ultimately caused by the fact that, in civil, contentious matters, Romanians compete with Belgians for first place as Europe’s most litigious peoples (European Union 2019:11, Fig.3).

32 On must also see these developments against the background of consistent over-subscription to magistrate school: there is no shortage of law school graduates who want to become judges or prosecutors; https://www.contributors.ro/desprejusti\%c8\%9bia-in-romania-de-ce-unele-segmente-ale-justi\%c8\%9biei-din-romania-nu-sunt-inca-mai-independente/ .

33 Organisational scholars will recognise an account of vacancy chains here (Chase 1991).

34 This is a testable claim by the time the 2021 data roll in. On the appropriate and fruitful uses of predictions in social science, see Collins (1995), and, from a totally different angle, Hofman, Sharma, and Watts (2017).

35 The importance that I place on explaining the mediation of causal tendencies by context is a direct consequence of the philosophy of science on which this article is premised, critical realism. Collier (1994) is the standard introduction to "core" Critical Realism. For those more interested in Critical Realism there is no substitute for reading Roy Bhaskar himself, a difficult but rewarding undertaking. On the importance of context I am also inspired by Nancy Cartwright (1999). 
retirements, as we would have expected if we had assumed that waves are always additive, and never reductive. ${ }^{36}$

A second phenomenon is the newly-formed rip-current, which is where a first wave alters the shoreline, creating conditions for the second, retreating wave to be funnelled and amplified in an unexpected way. Concretely, the fight over magistrate education has forged elite consensus on the importance of a continuous labour supply (i.e. a change in professional context) which is poised to funnel pent-up mobility (caused by the retreating COVID shockwave) and generate unusually large entry cohorts of judges and prosecutors. Here indeed one can speak of additive effects, but they are not due to changes in the professions themselves, but rather in their immediate context. This stress on context protects us against the internalising tendency of explanation - i.e. to always seek explanations of change from within - which is a useful approach for personal growth but a troublesome habit in social science.

\section{(6) Conclusion: Question the “Europe of Crises”}

This essay has attempted to introduce a new perspective on consecutive crises by reconceptualising them as sequential structural shockwaves, defined as singular event(s) of sufficient magnitude to rapidly retard or enable the causal tendencies of a social structure, in quick succession. The particular social structures I analysed were the Romanian state-based legal professions, judges and prosecutors (together known as magistrates), over the period 2016-2020, and the two shockwaves were the 20172019 reforms and the 2020 COVID-19 pandemic. Romania is a typical civil-law country with the unusual quality that its state-based legal professions have preserved their stability despite constant attack. The first feature makes conclusions from this case study relevant to other civil law countries, while the second makes it easier to analyse structural shocks.

The main methodological contribution of this piece is to introduce a new database of Romanian legal professions, which stretches from 1988 to the present day, and is constantly being updated as new data come online. The substantive conclusions are that politically-induced structural instability might have actually made the magisterial professions more robust to the COVID shock, and that (as of August 2020) we may be on the cusp of expansion in the number of judges and prosecutors. Theoretically, I have argued for the existence and analytic fruitfulness of two concepts drawn from maritime imagery: undertow and rip-currents. The former sensitises us to the potentially conflicting effects of sequential structural shocks, while the latter highlights the importance of context

It is important to note two key limitations to this research. First, it traces recent and unfolding events: the COVID-19 shockwave has not yet receded. Consequently, the results are vulnerable to reinterpretation as more data come in. In short, it is hard to shoot at a moving target. Another limitation lies in the nature of the measures. We have tried to detect structural shockwaves by studying changes in occupational mobility, much as one reasons about ocean waves by studying debris on the shore.

Mobility metrics are imperfect proxies, however, as there can be bureaucratic lag or error inn updating employment rolls, especially during a generalised quarantine. Other measures, such as anticipated changes in case-load or purchasing power, might more directly capture the issues at stake when judges and prosecutors decide whether or not they will retire or seek promotion.

That said, if there is a wider lesson for the analysis of governance and COVID-19 that I would like to communicate, it is that crises, or rather structural shocks, need not be additive, and that when they are, the additive effect may have more to do with context than with social structure. I argue that these possibilities provide an alternative to the lazy alarmism of "Europe in constant crisis" trope, which

36 I do not employ the imagery of wave interference (constructive or destructive) from physics because this metaphor allows for synchronous, overlapping waves. My theory, however, focuses strictly on sequential waves. 
substitutes crisis timelines (2009 recession, Greek sovereign debt, migrants, Brexit, COVID, etc.) for the close study of sequential phenomena, and which transforms every structural shock into an occasion to question the essence of things, usually of the European Union.

Of course, dramas in close succession matter, and many problems are endogenous, requiring us to reflect on internal processes. But these dramas may also generate no net effects, and the action that we do see might have more to do with the wind and sea than the soundness of the ship. At the very least, neither additivity nor explanatory internalism are self-evident $a$ priori. Strong and trenchant action and analysis, while reassuring that we're doing something, may produce worse consequences than doing nothing at all. Public negligence is rightly maligned, but public patience is underappreciated. The analysis of structural shockwaves can help us understand which is best suited for the task at hand.

\section{Works Cited}

Abbott, Andrew Delano. 1988. The System of Professions: An Essay on the Division of Expert Labor. Chicago: University of Chicago Press.

Bell, John. 2006. Judiciaries within Europe: A Comparative Review. Cambridge University Press.

Cartwright, Nancy. 1999. The Dappled World: A Study of the Boundaries of Science. Cambridge University Press.

Chase, Ivan D. 1991. "Vacancy Chains.” Annual Review of Sociology 17(1):133-154.

Collier, Andrew. 1994. Critical Realism: An Introduction to Roy Bhaskar’s Philosophy. London: Verso.

Collins, Randall. 1995. "Prediction in Macrosociology: The Case of the Soviet Collapse.” American Journal of Sociology 100(6):1552-93.

Crăcană, Iuliu. 2015. Dreptul în slujba puterii: justiția în regimul comunist din România, 1944-1958. Institutul Național pentru Studiul Totalitarismului.

European Union. 2019. 2019 EU Justice Scoreboard. Luxembourg: Publications Office of the European Union.

Gilliéron, Gwladys. 2014. Public Prosecutors in the United States and Europe: A Comparative Analysis with Special Focus on Switzerland, France, and Germany. Springer Science \& Business Media.

Hirschl, Ran. 2009. “The Judicialization of Politics.” Pp. 253-74 in The Oxford Handbook of Political Science, edited by R. E. Goodin. Oxford, UK: Oxford University Press.

Hofman, Jake M., Amit Sharma, and Duncan J. Watts. 2017. "Prediction and Explanation in Social Systems.” Science 355(6324):486-488.

Kovács, Kriszta, and Kim Lane Scheppele. 2018. “The Fragility of an Independent Judiciary: Lessons from Hungary and Poland-and the European Union." Communist and Post-Communist Studies 51(3):189-200. 
Meador, Daniel J. 1983. “German Appellate Judges: Career Patterns and American-English Comparisons.” Judicature 67(1):16-27.

Oliveira, Maria Angela Jardim de Santa Cruz, and Nuno Garoupa. 2011. “Choosing Judges in Brazil: Reassessing Legal Transplants from the United States.” The American Journal of Comparative Law 59(2):529-61.

Pierson, Paul. 2000. “Increasing Returns, Path Dependence, and the Study of Politics.” American Political Science Review 94(02):251-267.

Tamanaha, Brian Z. 2004. On the Rule of Law: History, Politics, Theory. Cambridge University Press.

White, Harrison C. 1995. "Network Switchings and Bayesian Forks: Reconstructing the Social and Behavioral Sciences.” Social Research 1035-1063.

Zerubavel, Eviatar. 1981. Hidden Rhythms: Schedules and Calendars in Social Life. University of Chicago Press.

\section{Appendix A: The Romanian Judicial System}

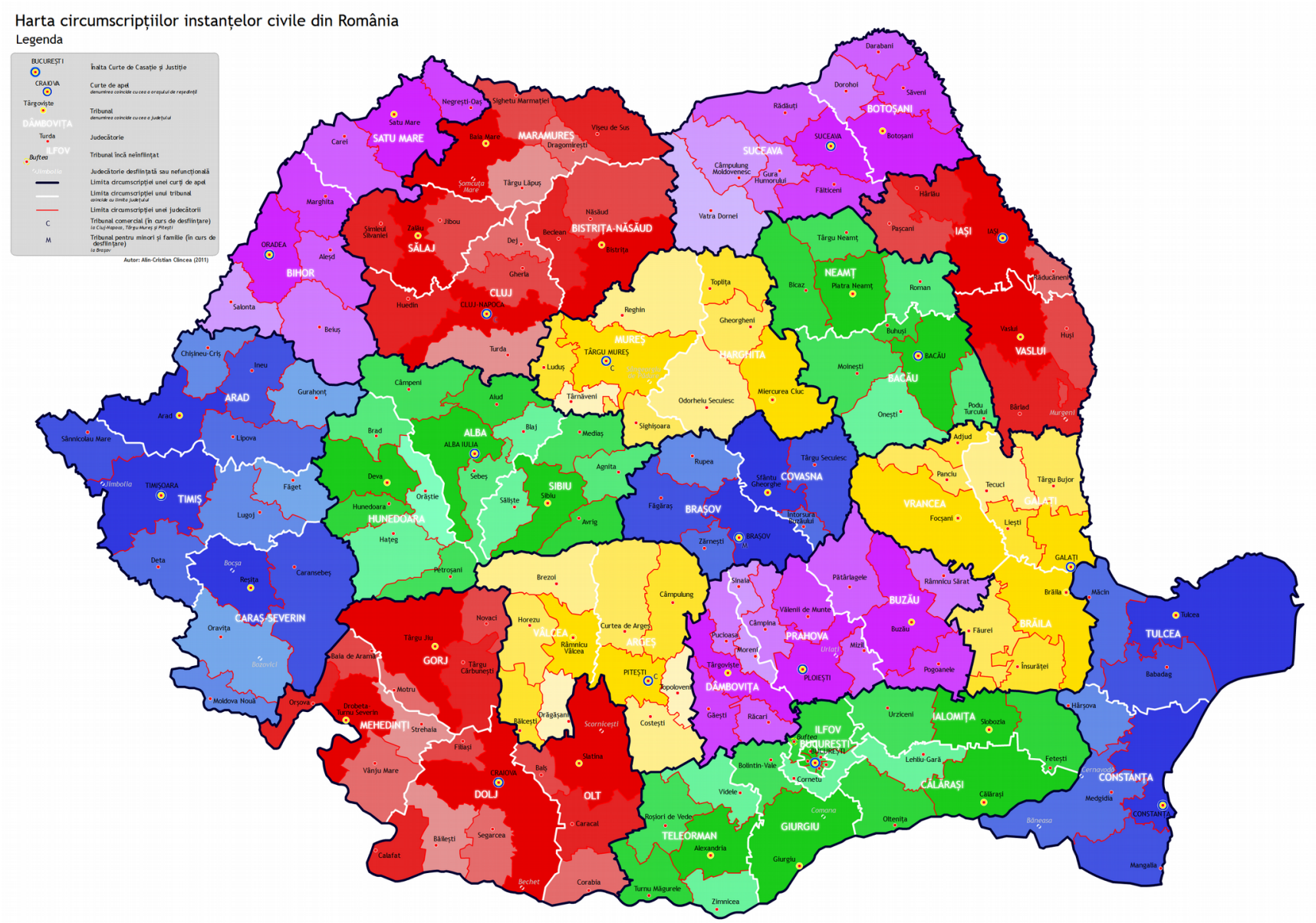

Figure 1A: The Territorial Structure of the Romanian Judiciary; courtesy of Wikipedia 
The Romanian judicial system has divided three broad components:

1. The military courts and prosecutors' offices (henceforth called "parquets), which I do not treat here.

2. The generalist, civilian courts and parquets, divided into 15 court of appeals regions (the coloured portions separated by dark lines in Figure 1A), 42 county tribunals (divided by white lines in Figure 1A), and 178 local courts (the town-level dots).

3. The large, elite, specialised prosecutor agencies, nominally focusing on either abuse of office or "corruption" (as does the National Anti-corruption Directorate, or the DNA) or counterterrorism and organised crime (the jurisdictions of the National Directorate for the Investigation of Terrorism and Organised Crime, or DIICOT). These agencies have their own internal, territorial structure largely mirroring the appeals areas, and each one employs as many prosecutors as the more populous appeals regions.

The territorial hierarchies of judges and prosecutors overlap almost entirely: each court has an associated parquet, whose territorial jurisdiction is identical to its court's. The principal exception to this overlap are the DNA and the DIICOT, which are nominally under the authority of the prosecutor general, who heads the generalist parquet hierarchy as Chief Prosecutor of the Parquet of the High Court of Cassation and Justice, or PICCJ. In reality however, they act independently.

There are also three small, specialised commercial courts with no affiliated parquets, prosecutors do not deal with civil matters, which I ignore. As of 2018 there is also the Special Section for the Investigation of Judicial Crime (SIIJ). These fifteen prosecutors investigate legal malfeasance among other judges and prosecutors. Finally, the common, official, and national-level professional organisation of both judges and prosecutors is the National Council of the Magistracy (CSM).

\section{Appendix B: A Brief History of Attempted Reforms of the Romanian Magistracy, January 2017 - October 2019}

Table B1 gives an inventory of the main laws (in Romanian, “acte normative”) introduced between 2017 and 2020 targetting important aspects of the state-based judicial professions. In addition to providing brief descriptions, I also note which structural aspect of the legal professions the law aimed to affect: organisation, jurisdiction, and size. All laws affected both judges and prosecutors, as they are a common legal category of "magistrate," unless otherwise noted. Before narrating and contextualising this sequence some technical terms require explanation.

"Bills” ("PL-x" in Romanian procedural terms) are legislative proposals that have not yet received presidential assent; after assent, a bill becomes "law”. Executive orders are marked as "OUG”, an acronym meaning "Emergency Government Ordinance.” For laws and executive orders, "Last notable date" indicates the date in which the law went into force, while for bills it is the date on which the bill passed its last parliamentary vote, before being reviewed by the constitutional court.

The first entry in the footnote associated with each legal act links to its most recent, official version. Second and third entries link to press articles explaining the particular bill/law/order and its implications: the evaluation is usually negative. All articles are in Romanian, and I have found (as of July 2020) that Romanian-English translations via Google communicate the gist of such pieces. Institutional acronyms (e.g. SIIJ, CSM) are explained in Appendix A. 


\begin{tabular}{|c|c|c|c|c|}
\hline $\begin{array}{l}\text { Bill / Law/ } \\
\text { Executive } \\
\text { Order }\end{array}$ & $\begin{array}{l}\text { Last Notable } \\
\text { Date }\end{array}$ & $\begin{array}{l}\text { Scope: this } \\
\text { act affects } \\
\text { professional }\end{array}$ & Details & $\begin{array}{l}\text { Status, as of } 8 \\
\text { August } 2020\end{array}$ \\
\hline $\begin{array}{c}\text { OUG } \\
13 / 2017^{37}\end{array}$ & $\begin{array}{l}31 \text { January, } \\
2017\end{array}$ & jurisdiction & $\begin{array}{l}\text { Alters the penal code to make it more } \\
\text { difficult to prosecute abuse of office } \\
\text { (generally, “corruption”) }\end{array}$ & \\
\hline $\begin{array}{l}\text { OUG } \\
14 / 2017^{38}\end{array}$ & $\begin{array}{l}5 \text { February, } \\
2017\end{array}$ & jurisdiction & Abrogates OUG 13/2017 & $\begin{array}{c}\text { Declared } \\
\text { constitutional on } \\
\text { April 9, } 2019\end{array}$ \\
\hline $\begin{array}{c}\text { Bill } \\
406 / 2018^{39}\end{array}$ & 4 July, 2018 & jurisdiction & $\begin{array}{l}\text { Alters the penal code to make it more } \\
\text { difficult to prosecute corruption }\end{array}$ & $\begin{array}{l}\text { Under review by the } \\
\text { Constitutional Court }\end{array}$ \\
\hline $\begin{array}{c}\text { Law } \\
207 / 2018^{40}\end{array}$ & 20 July, 2018 & structure & $\begin{array}{l}\text { Extensive organisational tinkering; } \\
\text { most notably, introduction of SIIJ }\end{array}$ & \\
\hline $\begin{array}{l}\text { OUG } \\
77 / 2018^{41}\end{array}$ & $\begin{array}{l}5 \text { September, } \\
2018\end{array}$ & structure & $\begin{array}{l}\text { Minster of Justice can now appoint } \\
\text { heads of the judicial control corps }\end{array}$ & \\
\hline $\begin{array}{c}\text { OUG } \\
90 / 2018^{42}\end{array}$ & $\begin{array}{l}10 \text { October, } \\
2018\end{array}$ & structure & $\begin{array}{l}\text { Fills organisational details to make } \\
\text { SIIJ operational }\end{array}$ & \\
\hline $\begin{array}{c}\text { Law } \\
234 / 2018^{43}\end{array}$ & $\begin{array}{l}11 \text { October, } \\
2018\end{array}$ & structure & Tinkers with the powers of CSM & \\
\hline $\begin{array}{c}\text { OUG } \\
92 / 2018^{44}\end{array}$ & $\begin{array}{l}16 \text { October } \\
2018\end{array}$ & $\begin{array}{l}\text { structure, } \\
\text { size }\end{array}$ & $\begin{array}{l}\text { Changes method for appointing heads } \\
\text { of PICCJ, changes seniority } \\
\text { requirements for PICCJ, DNA, and } \\
\text { DIICOT prosecutors, introduces } \\
\text { removal procedure of CSM members, } \\
\text { reduces magistrate retirement age, } \\
\text { increases minimum size of appeal } \\
\text { panels }\end{array}$ & $\begin{array}{l}\text { Clauses on } \\
\text { minimum age of } \\
\text { retirement and panel } \\
\text { sizes prorogued by } \\
\text { Law 239/2019 of } \\
\text { Dec } 19,2029 \text {, to } \\
2021 \text { and } 2022 \\
\text { respectively }\end{array}$ \\
\hline
\end{tabular}

37 http://legislatie.just.ro/Public/DetaliiDocumentAfis/186333 ; http://inliniedreapta.net/blogpost/ce-prevedea-ordonantade-urgenta-13-din-2017/

38 http://legislatie.just.ro/Public/DetaliiDocument/186389 ; https://www.g4media.ro/ccr-a-respins-toate-exceptiile-deneconstitutionalitate-ridicate-impotriva-oug-14-care-a-abrogat-oug-13-decizia-a-fost-luata-cu-unanimitate-devoturi.html

39 http://www.cdep.ro/pls/proiecte/upl pck2015.proiect?idp=17241 ; https://www.juridice.ro/607472/principalelemodificari-ale-codului-penal-si-codului-de-procedura-penala-plx-406-2018-si-plx-373-2018.html ; https://www.digi24.ro/stiri/actualitate/politica/cele-mai-nocive-13-modificari-aduse-codului-penal-de-coalitia-psd-alde$\underline{958024}$

40 http://legislatie.just.ro/Public/DetaliiDocumentAfis/203052

41 http://legislatie.just.ro/Public/DetaliiDocument/204519 ; https://ziare.com/tudorel-toader/ministrul-justitiei/csm-aavizat-negativ-ordonanta-data-cu-dedicatie-de-tudorel-toader-pentru-sefii-inspectiei-judiciare-1533532

42 http://legislatie.just.ro/Public/DetaliiDocumentAfis/205909 ; https://www.agerpres.ro/viataparlamentara/2018/11/12/camera-oug-90-2018-privind-sectia-pentru-investigarea-infractiunilor-din-justitie-adoptata-pearticole--209443

43 http://legislatie.just.ro/Public/DetaliiDocumentAfis/205492

44 http://legislatie.just.ro/Public/DetaliiDocumentAfis/206033 ; https://www.hotnews.ro/stiri-opinii-22761539-intelesultuturor-oug-92-modificare-legilor-justitiei.htm ; https://www.hotnews.ro/stiri-esential-22286368-bomba-ceas-din-legilejustitiei-care-goli-parchetele-instantele-superioare-apare-noua-categorie-tineri-pensionari-justitie.htm 


\begin{tabular}{|c|c|c|c|c|}
\hline $\begin{array}{l}\text { Law } \\
242 / 2018^{45}\end{array}$ & $\begin{array}{l}18 \text { October, } \\
2018\end{array}$ & $\begin{array}{l}\text { jurisdiction, } \\
\text { structure }\end{array}$ & $\begin{array}{l}\text { Alters legal definitions and attributes } \\
\text { of, prosecutors and magistrates are } \\
\text { and what they can do; notably } \\
\text { removes wording on independence of } \\
\text { prosecutors and increases length of } \\
\text { mandatory post-graduate magistrate } \\
\text { school from two to four years }\end{array}$ & $\begin{array}{l}\text { Increase in length of } \\
\text { magistrate school } \\
\text { reversed by OUG } \\
\text { 7/2019; struck down } \\
\text { by Constitutional } \\
\text { Court on } 10 \text { March, } \\
2020^{46}\end{array}$ \\
\hline $\begin{array}{l}\text { OUG } \\
7 / 2019^{47}\end{array}$ & $\begin{array}{l}20 \text { February, } \\
2019\end{array}$ & $\begin{array}{l}\text { structure, } \\
\text { size }\end{array}$ & $\begin{array}{l}\text { Changes method for appointing heads } \\
\text { of PICCJ, DNA and DIICOT; } \\
\text { transfers power from the Prosecutor } \\
\text { General to SIIJ; increases seniority } \\
\text { requirements for DNA and DIICOT; } \\
\text { prosecutors-turned-judges can } \\
\text { become chief prosecutors; revert to } \\
\text { old timeline for mandatory post- } \\
\text { graduate training }\end{array}$ & \\
\hline $\begin{array}{l}\text { Law } \\
239 / 2019^{48}\end{array}$ & $\begin{array}{l}\text { December } \\
19,2019\end{array}$ & structure & $\begin{array}{l}\text { Prorogues clauses of OUG 92/2018 } \\
\text { on 3-judge panels (effective only } \\
\text { from January 1, 2021) and on } \\
\text { lowering age of retirement (effective } \\
\text { only from January 1, 2022) }\end{array}$ & \\
\hline $\begin{array}{c}\text { OUG } \\
23 / 2020^{49}\end{array}$ & $\begin{array}{l}4 \text { February, } \\
2020\end{array}$ & jurisdiction & $\begin{array}{l}\text { Largely on public procurements; } \\
\text { notably, punishes judges if public } \\
\text { procurement cases take too long to } \\
\text { resolve }\end{array}$ & $\begin{array}{l}\text { Struck down by } \\
\text { Constitutional Court }\end{array}$ \\
\hline $\begin{array}{c}\text { Bill } \\
362 / 2019^{50}\end{array}$ & $\begin{array}{l}16 \text { June, } \\
2020\end{array}$ & size & $\begin{array}{l}\text { Taxes magistrates’ pension income by } \\
85 \% \text { above a fixed value }\end{array}$ & $\begin{array}{l}\text { Under review by the } \\
\text { Constitutional Court }\end{array}$ \\
\hline
\end{tabular}

Table B1: Detailed Chronology of Legal Reform Acts

45 http://legislatie.just.ro/Public/DetaliiDocument/205973 ; https://www.mediafax.ro/social/retrospectiva-2018modificarile-aduse-legilor-justitiei-si-codurilor-penale-motive-de-ingrijorare-in-legatura-cu-statul-de-drept-dinromania-actiunile-au-avut-ecouri-multiple-pe-plan-extern-17795682

46 https://lege5.ro/Gratuit/gm3timbxgiza/curtea-constitutionala-decizie-121-2020?dp=gmytomzxhe2dmni

47 http://legislatie.just.ro/Public/DetaliiDocumentAfis/211087 ; https://www.digi24.ro/stiri/actualitate/politica/guvernul-aaprobat-modificarea-legilor-justitiei-prin-ordonanta-de-urgenta-1084903

48 http://legislatie.just.ro/Public/DetaliiDocumentAfis/221101 ; https://www.mediafax.ro/politic/legea-privind-amanareapensionarii-anticipate-a-magistratilor-promulgata-de-presedintele-klaus-iohannis-18672506

49 http://legislatie.just.ro/Public/DetaliiDocument/223009 ; https:/www.digi24.ro/stiri/actualitate/ordonanta-de-urgentacare-modifica-legislatia-in-domeniul-achizitiilor-publice-este-neconstitutionala-decizie-ccr-1316972 ; http://www.unjr.ro/2020/02/16/contrar-referendumului-din-2019-guvernul-orban-a-modificat-prin-ordonanta-deurgenta-aspecte-ce-tin-de-legile-justitiei/

50 http://www.cdep.ro/pls/proiecte/upl pck2015.proiect?idp=18046; https://justitiecurata.ro/7-345-pensii-speciale-inromania-3-227-magistrati-beneficiari-pensia-medie-speciala-in-magistratura-e-de-9-400-lei/ ; https://www.digi24.ro/stiri/actualitate/ccr-amana-pentru-septembrie-decizia-privind-impozitarea-pensiilor-speciale$\underline{1337863}$ 
The story of the judicial reforms which constitute the first structural shockwave to hit the judicial professions began with the swelling ranks of politicians, businesspeople, magistrates, and civil servants indicted for corruption between 2005 and 2016. By the November 2016 legislative election, no politician was safe. Consequently, the new governing coalition (formed of the PSD-ALDE coalition, with reserve parliamentary support from UDMR; party acronyms explained in Appendix D) passed an executive order on January 31, 2017, which de-incriminated several abuse of office crimes, including one for which the head of the coalition was under investigation. This order was abrogated (via another executive order) a week later, after massive street protests.

Following a change of government (but not parties - familiar faces were shuffled around) the ruling coalition once more tried to push through reform, this time through legislative channels. The intent was signalled in summer 2017, ${ }^{51}$ and by fall an ad hoc "special" committee was created to shepherd reform bills through parliament. ${ }^{52}$ This committee's work was largely finished by summer-fall 2018, when numerous of its bills were passed by parliament. All the bills were referred by the opposition (the PNL, PMP, and USR parties, and the president) to the Constitutional Court, which nullified one one of the bills - the rest became law. During this time (fall-winter 2018) the government also caused judicial reform through highly controversial emergency ordinances.

Things quieted down at the beginning of 2019, as bills went through the Constitutional Court and as the politicians prepared for the May 2019 European elections, which were paired with a referendum on judicial reform. The ruling coalition did poorly in both the election and the referendum, and one day after the election the ruling party head was sent to jail for abuse of office. Summer 2019 witnessed a change in the parties in power: the newcomers (a PNL minority government) promised to undo the work of their predecessors, with patchy performance. ${ }^{53}$ The fall 2019 presidential election was handily won by the incumbent candidate who opposed the judicial reform. In September 2019, two years after being founded, the special parliamentary committee on legal reform was disbanded. ${ }^{54}$

The new parliamentary power attempted two further reforms in winter-spring 2020, one to shorten the time that it takes to settle lawsuits regarding public procurements, the second to reduce the pensions of judges and prosecutors. As of this writing (August 8, 2020) the first initiative has been struck down by the Constitutional Court, while the second remains under review. COVID-19 has shifted political priorities away from legal reforms, and local and parliamentary elections are expected to take place in fall 2020.

\section{Appendix C: Periodisation and the Distinction between the 2017-2019 and 2020 Shockwaves}

The periodisation that I adopt for this essay is that the shockwave of judicial reforms began with OUG 13/2017 on January 31 $1^{\text {st }}$, 2017 and ended with the demise of the PSD-ALDE government after the successful motion of confidence on October $10^{\text {th }}, 2019$. I do not count the three legal acts after October $10^{\text {th }}$ (see Appendix B above) as part of this wave, because:

a) the new government explicitly, and successfully, sold itself as a counter-reformer

51 http://www.just.ro/en/principalele-modificari-propuse-la-legile-justitiei-legea-nr-3032004-legea-nr-3042004-si-legea$\underline{\mathrm{nr}-3172004 /}$

52 http://www.cdep.ro/pls/proiecte/upl com2015.lista?idc=221\&an=2017

53 https://www.bursa.ro/guvern-legile-justitiei-vor-fi-modificate-in-parlament-63314933 ; https://romania.europalibera.org/a/cum-se-schimba-legile-justi\%C8\%9Biei/30653054.html ;

https://www.digi24.ro/stiri/actualitate/politica/klaus-iohannis-anunta-un-nou-pachet-de-legi-ale-justitiei-legile-psdtrebuie-reparate-1317305

54 https://stirileprotv.ro/stiri/actualitate/comisia-lui-iordache-care-a-modificat-legile-justitiei-in-parlament-a-fostdesfiintata.html 
b) Law 239/2019 of December 19, 2019 actualised this counter-reformation, proroguing articles from earlier reform laws

c) OUG 23/2020 only tangentially dealt with judges, being primarily about public-procurements

d) both OUG 23/2020 and Bill 362/2019 (passed by parliament in 16 June 2020) have yet to gain effect, the first being struck down by the Constitutional Court, the second remaining under court review as of August 8, 2020

Therefore, even if it could be argued that the PNL minority government is subtly furthering the reform agenda of its predecessor (an interpretation which can only be maintained by focusing exclusively on Bill 362/2019), the fact of the matter is the only PNL-era law to actually taken effect (as of August 8, 2020 ) is the counter-reformation law, i.e. 239/2019. Consequently, one can confidently state the structural shockwave associated with the PSD-ALDE-UDMR reforms ended in Fall 2019, having probably peaked in spring 2019 with OUG 7/2019. By the time we entered the COVID-19 state of emergency in March 2020, we were dealing with a new and distinct shockwave.

\section{Appendix D: Party Names and Acronyms}

PNL: "Partidul Naţional Liberal” ; National Liberal Party

PSD: "Partidul Social Democrat"; Social Democratic Party

ALDE: “Alianţa Liberalilor şi Democraţilor” ; Alliance of Liberals and Democrats

PMP: "Partidul Mişcarea Populară” ; Popular Movement Party

USR: “Uniunea Salvaţi România” ; Save Romania Union

UDMR: “Uniunea Democrată Maghiară din România”, “Romániai Magyar Demokrata Szövetség”; Democratic Alliance of Hungarians in Romania 